\title{
Storage Method Influences the Fatty Acid Composition in Groundnut during Post-Harvest
}

\author{
Y. Swathi*, P. Rajanikanth and J. Satyanarayana \\ Professor Jayashankar Telangana State Agricultural University, Rajendranagar, \\ Hyderabad, Telangana, India \\ *Corresponding author
}

A B S T R A C T

Keywords

Groundnut, Aspergillus flavus, Caryedon serratus, Fatty acid composition.

Article Info

Accepted: 07 September 2017 Available Online:

10 October 2017
Groundnut is an important food legume in tropical, sub-tropical and temperate countries of the world. In India, groundnut is grown in an area of 5.53 million ha with a production and productivity of 9.67 million tons and $1750 \mathrm{~kg} / \mathrm{ha}$ respectively. Groundnut quality is usually affected by storage practices and storage periods. In our present study, an experiment was carried out to study the nutritional changes that occur in groundnut during storage under the influence of Caryedon serratus and Aspergillus flavus. Results indicate the total unsaturated fatty acids, oil and protein contents were decreased and saturated fatty acids were increased. This could be due to interaction effect of insect and fungi in storage of groundnut pods in different storage bags at different moisture levels of 10 and $14 \%$.

\section{Introduction}

Groundnut (Peanut; Arachis hypogaea L.) is an important food legume and an oil seed crop. In India, it is cultivated in an area of 5.53 million ha with annual production of 9.67 million tons and productivity of $1750 \mathrm{~kg}$ ha $^{-1}$ which makes India second largest producer after China (India stat, 2013-14). In Telangana state, groundnut is grown in an area of 0.21 million ha with annual production of 0.355 million tons and productivity of $1320 \mathrm{~kg} \mathrm{ha}^{-1}$ (Statistical year book of Telangana 2015).

In agriculture, seeds play very important role for the production of healthy crop. Seeds in the field as well as in the storage interact with several microbes which deteriorate the seed health, both qualitatively and quantitatively (Christensen and Kaufman, 1969).

Fungi growing on stored grains may negatively affect the germination percentage, carbohydrates, protein, total oil content, and also brought other biochemical changes (Bhattacharya, 2002).In a previous study, it was observed a decrease in germination percentage, oil and protein content and an increase in free fatty acid content in stored groundnut kernels (Ramamurthy and Karivaratharaju, 1989). 
Similarly, in another study significant increase in free fatty acid content of groundnut stored for a period of six months in jute bags and polythene bag observed. Further significantly low free fatty acid content observed in groundnut stored in jute bag doubled with thin polyethylene and jute bag doubled with thick polythene and opined that increase in A. flavus build up as the probable reason for increased free fatty acid content (Bulaong and Dharmaputra, 2002).

\section{Materials and Methods}

Ten kilograms of groundnut pods of $\mathrm{cv}$. ICGV 02266with moisture contents of $10 \%$ and $14 \%$ were weighed separately and placed in each of four treatment bags such as jute bags, polypropylene bags, triple layer plastic bags and jute bags treated with spinosad. Each of these bags was infested with 30 pairs of adult bruchids and spore suspension of Aspergillus flavus toxigenic strain @ 15 $\mathrm{ml} / \mathrm{bag}$. The bags were then moved gently upside and down for uniform mixing of $A$. flavus spore suspension and adult bruchids before closing the bags. The storage bags (one layer at a time starting with the inner most in the case of triple layer bags) were then tied manually by twisting the loose end of the bag around and folding it over then tying it tightly at the base of the twist and around the folded loop using a strong thread.

Each of the four bags used for the experiment were replicated thrice for given moisture percentage hence, a total of 24 such storage bags were formed as a batch. Three such batches were formed which were tested for bruchid damage and fungal infestation and subsequent aflatoxin accumulation after an interval of 2, 4 and 6 months of storage.

The fatty acid composition was estimated by using Near Infrared Reflectance Spectroscopy (NIRS; model XDSRCA, FOSS Analytical
AB, Sweden, Denmark) which is a nondestructive method of estimating biochemical constituents. The oil and fatty acid composition of groundnut seeds at two different moisture regimes was estimated a day before setting up of the experiment by drawing a representative sample of pods which were shelled to obtain approximately 70-100 grams of kernels. The kernels so obtained were placed in a small rectangular cup of the NIRS equipment and allowed to scan. The scanned sample was then analysed by the equipment and data for total compositions of different fatty acids viz., palmitic acid, stearic acid, oleic acid, and linoleic content etc. was displayed by the equipment on its monitor which was recorded.

\section{Results and Discussion}

Our results indicate significant changes in unsaturated fatty acids (Oleic and Linoleic) and saturated fatty acids (Palmitic and Stearic) at the end of 6 months storage with respect to different storage methods. However, minimum biochemical changes were recorded after 2 months of storage in comparison to 4 and 6 months of storage across all storage treatments. Further, the changes were minimal at $10 \%$ moisture levels in comparison to $14 \%$ moisture levels. Among the different bags used for storage, minimum changes in biochemical constitutes were observed in triple layer plastic bags stored product, whereas maximum changes were recorded in jute bag stored product.

Changes in unsaturated fatty acid composition at different moisture levels at different storage periods

There was a significant variation in per cent changes of the total unsaturated fatty acid content in different storage bags at different moisture levels. The maximum reduction in linoleic and oleic acid content was recorded in 
jute bag (25.53, 25.05 and 24.89 and 48.92, $47.31 \& 46.66)$ at $14 \%$ moisture levels in comparison to $10 \%$ moisture $(30.38,29.09$ $\& 28.00$ and 53.00, 52.93 and 50.23) after 2, 4 and 6 months of storage respectively. The minimal reduction of linoleic and oleic acid content was recorded in triple layer plastic bag at 14 and $10 \%$ moisture levels (Tables 1 and 2).

The individual effect of bag type, moisture and interaction of both reveal that maximum percent reduction in total unsaturated fatty acid content was recorded in jute bag at $14 \%$ moisture level and minimum decrease was recorded in triple layer bag at $10 \%$ moisture levels.

\section{Changes in saturated fatty acid composition at different moisture levels at different sets of storage period}

The percent palmitic and stearic acid content of groundnut pods (Tables 3 and 4) increased from 14.86-16.54 and 3.74-3.88 was recorded in jute bag at $14 \%$ moisture levels in comparison to $10 \%$ moisture (10.19-14.96 and 3.40-3.58) after 2, 4 and 6 months storage respectively. The minimal per cent reduction of palmitic and stearic acid content was recorded in triple layered bag at 14 (9.8-14.07 and 3.06-3.34) and 10\% (8.73-13.43 and 3.053.30) moisture levels respectively. The effect bag type revealed that the maximum content of palmitic and stearic was recorded in jute bag followed jute bag treated with spinosad and polythene bag. The minimal increase was recorded in triple layer bag after 2, 4 and 6 months storage period. In a previous study, Gopinath et al., (2011) reported that high moisture levels favour the multiplication of fungi and insects and also the lipoxygenase activity inside the kernels increases the lipid deterioration as lipids were used as substrate for their growth. Due to lipolytic activity of pods and fungi results in lipid deterioration which further leads to decrease unsaturated fatty acids (linoleic, oleic), oil and protein content and increase the saturated fatty acids (stearic, palmitic) content.

Further our results were in agreement with Weinberg et al., (2008) as triple layer plastic bag protect the storable product from external environment against oxygen, relative humidity and temperature as its bag structure with three layers would not allow the external oxygen, relative humidity and temperature and a proportional decrease in oxygen and increase in carbon dioxide with no changes in moisture under sealed conditions were major factors in changes in acid content, whereas jute bag, jute bag treated with spinosad and polythene bags were gain the external oxygen moisture, relative humidity and temperature. Major changes in linoleic and oleic acid contents occurred in jute bags due to insect and fungal multiplication by utilizing the oxygen which was available and also increased pod moisture, relative humidity and temperature dictate microorganisms and insect degrade the storage groundnut pods (Magan et al., 2003).

The saturated fatty acids (stearic and palmitic) were increased on storage in pods stored traditional storage bags at $14 \%$ moisture in comparison to $10 \%$ moisture and also triple layer bags. These results were in agreement with Roberts et al., (1987)who observed an increase in free fatty acids (palmitic and stearic acid) due to lipolytic activity of fungus as lipids are triglycerides and their hydrolysis leads to formation of free fatty acids and glycerol which cause the deterioration of kernels. Jubeen et al., (2012) reported that the maximum increase in saturated free fatty acids (stearic and palmitic) observed in the pods stored at higher moisture $(16 \pm 3 \%)$ levels in comparison to the pods with low moisture $(10 \pm 3 \%)$. This could be majorly due to decrease in oxidation index $\left(\sum \mathrm{UFA} / \sum \mathrm{SFA}\right)$ in storage periods at different moisture levels. 
Table.1 Effect of storage bags and pod moisture content on per cent change in oleic acid content at different storage periods

\begin{tabular}{|c|c|c|c|c|}
\hline \multicolumn{5}{|c|}{$\begin{array}{c}\text { Per cent changes in oleic acid content in different storage bags with different } \\
\text { moisture levels }\end{array}$} \\
\hline \multirow[b]{3}{*}{ Per cent moisture } & & 2 Months & 4 Months & 6 Months \\
\hline & 10 & $54.22^{\mathrm{a}}$ & $53.80^{\mathrm{a}}$ & $52.07^{\mathrm{a}}$ \\
\hline & 14 & $51.47^{\mathrm{b}}$ & $50.38^{\mathrm{b}}$ & $49.79^{b}$ \\
\hline \multicolumn{2}{|c|}{ S.E(m) } & 0.08 & 0.24 & 0.14 \\
\hline \multicolumn{2}{|c|}{ C. $\mathrm{D}(\mathrm{P}=0.01)$} & 0.34 & 1.02 & 0.61 \\
\hline \multirow{4}{*}{ Bag type } & $\begin{array}{l}\text { Triple layer } \\
\text { plastic bag }\end{array}$ & $55.73^{\mathrm{a}}$ & $55.00^{\mathrm{a}}$ & $54.00^{\mathrm{a}}$ \\
\hline & $\begin{array}{l}\text { Polypropylene } \\
\text { bag }\end{array}$ & $52.71^{\mathrm{b}}$ & $52.02^{\mathrm{b}}$ & $51.01^{\mathrm{b}}$ \\
\hline & $\begin{array}{l}\text { Jute bag treated } \\
\text { with Spinosad }\end{array}$ & $52.00^{\mathrm{b}}$ & $51.22^{b c}$ & $50.27^{\mathrm{b}}$ \\
\hline & Jute bag & $50.96^{\mathrm{d}}$ & $50.12^{\mathrm{c}}$ & $48.44^{\mathrm{c}}$ \\
\hline \multicolumn{2}{|c|}{ S.E(m) } & 0.11 & 0.35 & 0.2 \\
\hline \multicolumn{2}{|c|}{ C. $\mathrm{D}(\mathrm{P}=0.01)$} & 0.48 & 1.45 & 0.86 \\
\hline \multicolumn{5}{|c|}{ Interaction (Moisture x Bag type) } \\
\hline \multirow{4}{*}{$10 \%$} & $\begin{array}{l}\text { Triple layer } \\
\text { plastic bag }\end{array}$ & $55.90^{\mathrm{a}}$ & $55.50^{\mathrm{a}}$ & $54.20^{\mathrm{a}}$ \\
\hline & $\begin{array}{l}\text { Polypropylene } \\
\text { bag }\end{array}$ & $54.66^{\mathrm{b}}$ & $53.63^{\mathrm{ab}}$ & $52.00^{\mathrm{b}}$ \\
\hline & $\begin{array}{l}\text { Jute bag treated } \\
\text { with Spinosad }\end{array}$ & $53.34^{\mathrm{c}}$ & $53.14^{\mathrm{b}}$ & $51.86^{\mathrm{b}}$ \\
\hline & Jute bag & $53.00^{\mathrm{c}}$ & $52.93^{\mathrm{b}}$ & $50.23^{c}$ \\
\hline \multirow{4}{*}{$14 \%$} & $\begin{array}{l}\text { Triple layer } \\
\text { plastic bag }\end{array}$ & $55.56^{\mathrm{a}}$ & $54.50^{\mathrm{ab}}$ & $53.80^{\mathrm{a}}$ \\
\hline & $\begin{array}{l}\text { Polypropylene } \\
\text { bag }\end{array}$ & $50.76^{\mathrm{d}}$ & $50.42^{c}$ & $50.02^{c}$ \\
\hline & $\begin{array}{l}\text { Jute bag treated } \\
\text { with Spinosad }\end{array}$ & $50.66^{\mathrm{d}}$ & $49.30^{\mathrm{cd}}$ & $48.68^{d}$ \\
\hline & Jute bag & $48.92^{\mathrm{e}}$ & $47.31^{\mathrm{d}}$ & $46.66^{\mathrm{e}}$ \\
\hline \multicolumn{2}{|c|}{ S.E(m) } & 0.16 & 0.5 & 0.3 \\
\hline \multicolumn{2}{|c|}{ C. $\mathrm{D}(\mathrm{P}=0.01)$} & 0.7 & 2.05 & 1.22 \\
\hline
\end{tabular}

*Values followed by the same letter are not significantly different 
Table.2 Effect of storage bags and pod moisture content on per cent change in linoleic acid content at different storage periods

\begin{tabular}{|c|c|c|c|c|}
\hline \multicolumn{5}{|c|}{ Per cent change in linoleic acid in different storage bags } \\
\hline & & 2 Months & 4Months & 6 Months \\
\hline \multirow{2}{*}{ Per cent moisture } & 10 & $32.04^{\mathrm{a}}$ & $31.29^{\mathrm{a}}$ & $30.13^{\mathrm{a}}$ \\
\hline & 14 & $29.92^{b}$ & $28.88^{\mathrm{b}}$ & $27.26^{\mathrm{b}}$ \\
\hline \multicolumn{2}{|c|}{ S.E $(\mathrm{m})$} & 0.06 & 0.11 & 0.11 \\
\hline \multicolumn{2}{|c|}{ C.D $(\mathrm{P}=0.01)$} & 0.28 & 0.48 & 0.47 \\
\hline \multirow{4}{*}{ Bag type } & Triple layer plastic bag & $34.92^{\mathrm{a}}$ & $33.66^{\mathrm{a}}$ & $31.54^{\mathrm{a}}$ \\
\hline & Polypropylene bag & $30.70^{\mathrm{b}}$ & $30.02^{\mathrm{b}}$ & $28.96^{\mathrm{b}}$ \\
\hline & $\begin{array}{l}\text { Jute bag treated with } \\
\text { Spinosad }\end{array}$ & $30.30^{\mathrm{b}}$ & $29.49^{b}$ & $27.43^{\mathrm{c}}$ \\
\hline & Jute bag & $28.00^{\mathrm{c}}$ & $27.17^{\mathrm{c}}$ & $26.86^{\mathrm{c}}$ \\
\hline \multicolumn{2}{|c|}{$\mathrm{S} . \mathrm{E}(\mathrm{m})$} & 0.09 & 0.16 & 0.16 \\
\hline \multicolumn{2}{|c|}{ C.D $(\mathrm{P}=0.01)$} & 0.4 & 0.7 & 0.67 \\
\hline \multicolumn{5}{|c|}{ Interaction (Moisture x Bag type) } \\
\hline \multirow{4}{*}{$10 \%$} & Triple layer plastic bag & $36.01^{\mathrm{a}}$ & $34.93^{\mathrm{a}}$ & $32.05^{\mathrm{a}}$ \\
\hline & Polypropylene bag & $31.03^{\mathrm{c}}$ & $30.96^{c}$ & $29.92^{\mathrm{c}}$ \\
\hline & $\begin{array}{l}\text { Jute bag treated with } \\
\text { Spinosad }\end{array}$ & $30.65^{\mathrm{cd}}$ & $29.99^{\mathrm{cd}}$ & $29.74^{\mathrm{cd}}$ \\
\hline & Jute bag & $30.48^{\text {cde }}$ & $29.30^{\mathrm{d}}$ & $28.83^{\mathrm{de}}$ \\
\hline \multirow{4}{*}{$14 \%$} & Triple layer plastic bag & $33.83^{\mathrm{b}}$ & $32.40^{\mathrm{b}}$ & $31.03^{\mathrm{b}}$ \\
\hline & Polypropylene bag & $30.38^{\mathrm{d}}$ & $29.09^{\mathrm{de}}$ & $28.00^{\mathrm{e}}$ \\
\hline & $\begin{array}{l}\text { Jute bag treated with } \\
\text { Spinosad }\end{array}$ & $29.95^{\mathrm{e}}$ & $29.00^{\mathrm{e}}$ & $25.13^{\mathrm{f}}$ \\
\hline & Jute bag & $25.53^{\mathrm{f}}$ & $25.05^{\mathrm{f}}$ & $24.89^{\mathrm{f}}$ \\
\hline \multicolumn{2}{|c|}{ S.E (m) } & 0.13 & 0.23 & 0.23 \\
\hline \multicolumn{2}{|c|}{ C. $\mathrm{D}(\mathrm{P}=0.01)$} & 0.56 & 0.97 & 0.95 \\
\hline
\end{tabular}

*Values followed by the same letter are not significantly different 
Table.3 Effect of storage bags and pod moisture content on per cent change in palmitic acid content at different storage periods

\begin{tabular}{|c|c|c|c|c|}
\hline \multicolumn{5}{|c|}{$\begin{array}{c}\text { Per cent changes in palmitic acid content in different storage bags at different } \\
\text { moisture levels }\end{array}$} \\
\hline & & 2 Months & 4Months & 6 Months \\
\hline \multirow[b]{2}{*}{ Per cent moisture } & 10 & $9.65^{\mathrm{a}}$ & $13.57^{\mathrm{a}}$ & $14.32^{\mathrm{a}}$ \\
\hline & 14 & $11.99^{b}$ & $14.67^{b}$ & $15.21^{\mathrm{b}}$ \\
\hline \multicolumn{2}{|c|}{ S.E(m) } & 0.03 & 0.03 & 0.01 \\
\hline \multicolumn{2}{|c|}{ C. $D(P=0.01)$} & 0.12 & 0.13 & 0.06 \\
\hline \multirow{4}{*}{ Bag type } & $\begin{array}{c}\text { Triple layer plastic } \\
\text { bag }\end{array}$ & $9.26^{\mathrm{a}}$ & $12.61^{\mathrm{a}}$ & $13.75^{\mathrm{a}}$ \\
\hline & Polypropylene bag & $10.09^{b}$ & $14.38^{\mathrm{b}}$ & $14.61^{\mathrm{b}}$ \\
\hline & $\begin{array}{l}\text { Jute bag treated } \\
\text { with Spinosad }\end{array}$ & $11.42^{\mathrm{c}}$ & $14.62^{c}$ & $14.96^{\mathrm{c}}$ \\
\hline & Jute bag & $12.52^{\mathrm{d}}$ & $14.88^{\mathrm{d}}$ & $15.75^{\mathrm{d}}$ \\
\hline \multicolumn{2}{|c|}{ S.E(m) } & 0.04 & 0.04 & 0.02 \\
\hline \multicolumn{2}{|c|}{ C. $\mathrm{D}(\mathrm{P}=0.01)$} & 0.18 & 0.2 & 0.08 \\
\hline \multicolumn{5}{|c|}{ Interaction (Moisture x Bag type) } \\
\hline \multirow{4}{*}{$10 \%$} & $\begin{array}{c}\text { Triple layer plastic } \\
\text { bag }\end{array}$ & $8.73^{\mathrm{a}}$ & $11.93^{\mathrm{a}}$ & $13.43^{\mathrm{a}}$ \\
\hline & Polypropylene bag & $9.82^{\mathrm{b}}$ & $13.90^{\mathrm{c}}$ & $14.16^{\mathrm{b}}$ \\
\hline & $\begin{array}{l}\text { Jute bag treated } \\
\text { with Spinosad }\end{array}$ & $9.88^{\mathrm{b}}$ & $14.04^{\mathrm{c}}$ & $14.73^{c}$ \\
\hline & Jute bag & $10.19^{c}$ & $14.43^{\mathrm{d}}$ & $14.96^{\mathrm{d}}$ \\
\hline \multirow{4}{*}{$14 \%$} & $\begin{array}{c}\text { Triple layer plastic } \\
\text { bag }\end{array}$ & $9.8^{\mathrm{b}}$ & $13.30^{\mathrm{b}}$ & $14.07^{\mathrm{b}}$ \\
\hline & Polypropylene bag & $10.36^{\mathrm{c}}$ & $14.86^{\mathrm{e}}$ & $15.07^{\mathrm{d}}$ \\
\hline & $\begin{array}{l}\text { Jute bag treated } \\
\text { with Spinosad }\end{array}$ & $12.96^{\mathrm{d}}$ & $15.20^{\mathrm{f}}$ & $15.19^{\mathrm{e}}$ \\
\hline & Jute bag & $14.86^{\mathrm{e}}$ & $15.33^{\mathrm{f}}$ & $16.54^{\mathrm{f}}$ \\
\hline \multicolumn{2}{|c|}{ S.E(m) } & 0.06 & 0.06 & 0.028 \\
\hline \multicolumn{2}{|c|}{ C. $\mathrm{D}(\mathrm{P}=0.01)$} & 0.25 & 0.27 & 0.11 \\
\hline
\end{tabular}

*Values followed by the same letter are not significantly different 
Table.4 Effect of storage bags and pod moisture content on per cent change in stearic acid content at different storage periods

\begin{tabular}{|c|c|c|c|c|}
\hline \multicolumn{5}{|c|}{$\begin{array}{c}\text { Per cent changes in stearic acid content in different storage bags at different } \\
\text { moisture levels }\end{array}$} \\
\hline & & 2 Months & 4Months & 6 Months \\
\hline \multirow[b]{2}{*}{ Per cent moisture } & 10 & $3.21^{\mathrm{a}}$ & $3.43^{\mathrm{a}}$ & $3.47^{\mathrm{a}}$ \\
\hline & 14 & $3.46^{\mathrm{b}}$ & $3.60^{\mathrm{b}}$ & $3.66^{\mathrm{b}}$ \\
\hline \multicolumn{2}{|c|}{ S.E(m) } & 0.02 & 0.01 & 0.005 \\
\hline \multicolumn{2}{|c|}{ C. $\mathrm{D}(\mathrm{P}=0.01)$} & 0.08 & 0.04 & 0.02 \\
\hline \multirow{4}{*}{ Bag type } & $\begin{array}{l}\text { Triple layer plastic } \\
\text { bag }\end{array}$ & $3.06^{\mathrm{a}}$ & $3.29^{\mathrm{a}}$ & $3.32^{\mathrm{a}}$ \\
\hline & Polypropylene bag & $3.32^{b}$ & $3.52^{b}$ & $3.54^{\mathrm{b}}$ \\
\hline & $\begin{array}{l}\text { Jute bag treated } \\
\text { with Spinosad }\end{array}$ & $3.41^{\mathrm{b}}$ & $3.59^{\mathrm{c}}$ & $3.67^{\mathrm{c}}$ \\
\hline & Jute bag & $3.57^{\mathrm{c}}$ & $3.67^{\mathrm{d}}$ & $3.73^{\mathrm{d}}$ \\
\hline \multicolumn{2}{|c|}{ S.E(m) } & 0.03 & 0.016 & 0.007 \\
\hline \multicolumn{2}{|c|}{ C. $\mathrm{D}(\mathrm{P}=0.01)$} & 0.11 & 0.05 & 0.026 \\
\hline \multicolumn{5}{|c|}{ Interaction (Moisture x Bag type) } \\
\hline \multirow{4}{*}{$10 \%$} & $\begin{array}{l}\text { Triple layer plastic } \\
\text { bag }\end{array}$ & $3.05^{\mathrm{a}}$ & $3.27^{\mathrm{a}}$ & $3.30^{\mathrm{a}}$ \\
\hline & Polypropylene bag & $3.12^{\mathrm{ab}}$ & $3.41^{\mathrm{b}}$ & $3.44^{\mathrm{b}}$ \\
\hline & $\begin{array}{l}\text { Jute bag treated } \\
\text { with Spinosad }\end{array}$ & $3.28^{\mathrm{bc}}$ & $3.52^{c}$ & $3.56^{\mathrm{c}}$ \\
\hline & Jute bag & $3.40^{\mathrm{cd}}$ & $3.54^{\mathrm{c}}$ & $3.58^{c}$ \\
\hline \multirow{4}{*}{$14 \%$} & $\begin{array}{l}\text { Triple layer plastic } \\
\text { bag }\end{array}$ & $3.06^{\mathrm{a}}$ & $3.31^{\mathrm{a}}$ & $3.34^{\mathrm{a}}$ \\
\hline & Polypropylene bag & $3.52^{\mathrm{d}}$ & $3.63^{\mathrm{d}}$ & $3.64^{\mathrm{d}}$ \\
\hline & $\begin{array}{l}\text { Jute bag treated } \\
\text { with Spinosad }\end{array}$ & $3.54^{\mathrm{d}}$ & $3.67^{d}$ & $3.79^{\mathrm{e}}$ \\
\hline & Jute bag & $3.74^{\mathrm{e}}$ & $3.81^{\mathrm{e}}$ & $3.88^{\mathrm{f}}$ \\
\hline \multicolumn{2}{|c|}{$\mathrm{S} . \mathrm{E}(\mathrm{m})$} & 0.04 & 0.02 & 0.009 \\
\hline \multicolumn{2}{|c|}{ C. $\mathrm{D}(\mathrm{P}=0.01)$} & 0.17 & 0.08 & 0.04 \\
\hline
\end{tabular}

*Values followed by the same letter are not significantly different 
Shin et al., (1997) observed decrease in polyunsaturated fatty acids and increase in saturated fatty acids content in nuts stored at high moisture level. The maximum reduction of unsaturated and increase of saturated fatty acids content was recorded in jute bag due to presence of oxygen and at high moisture levels. These results are agreement with Chang et al., (2004) reported rapid deterioration of soybean occurred by auto oxidation of lipids due to storage of seed with high moisture content in presence of oxygen.

Jain (2008) reported a rapid increase in concentration of free fatty acids in damaged groundnut kernels during storage due to fungal invasion.

Mutegi et al., (2013) reported in another study on groundnuts stored for six months in jute, polypropylene, and polyethylene bags that rancidity ranged from 0.8 to 5.3 and increased with storage duration from a mean of 1.5 before storage to a peak of 2.5 after 5 months of storage.

The study has demonstrated that the pods stored in triple layer plastic bags at low moisture (10\%) gave good level of protection against decrease in unsaturated fatty acids and increase saturated fatty acids in comparison to traditional storage bags. There is an urgent need to increase awareness among farmers in aspects of the importance of hermetic storage technologies especially using triple layer plastic bags for storage of their product without loss of desirable qualities of stored product.

\section{Acknowledgements}

Authors acknowledge the ICRISAT for the financial support to undertake this study through its CGIAR Research ProgramAgriculture for Nutrition and Health (CRPA4NH).

\section{References}

Bhattacharya, K., and Raha, S. 2002. Deteriorative changes of maize, groundnut and soybean seeds by fungi in storage. Mycopathologia. 155: 135141.

Bulaong, S.S.P., and Dharmaputra, O.S. 2002. Fungal population, aflatoxin and free fatty acid contents of peanuts packed in different bag types. Biotropia. 19: 1-25.

Chang, S.K.C., Liu, Z.S., Hou, H.J and Wilson, L.A. 2004. Influence of storage on the characteristics of soybean, soymilk and tofu. Proc. VII- World Soybean Res. Con., IV-In: Soybean Proc. and Util. Con., III- Congress Brasileiro de Soja Brazilian Soybean Congress, Foz do Iguassu, PR, Brazil. pp. 977-983.

Christensen, C.M., and Kaufman, H.H. 1969. Grain storage. The role of fungi in quality losses. Univ. Minnesota, Press Minneapolis.

Gopinath, M.R., Sambiah, K and Niranjana, S.R. 2011. Effect of Storage on Red gram (Cajanus cajan L. Mill sp) and Green gram (Vigna radiata L.) with Particular Reference to Lipid Composition. Plant Protection Science. 47 (4): 157-165.

India stat, 2013-14. India's comprehensive statistics information portal; India Stathttp://www.indiastat.com.

Jain, P.C., 2008. Applied microbiology: Microbial degradation of grains, oil seeds, textiles, wood, and corrosion of metals and bioleaching of mineral ores. pp: 1-37.

Jubeen, F., I.A. Bhatti, U. Maqbool and S. Mehboob. 2012. Fungal incidence, aflatoxin B1, tocopherols and fatty acids dynamics in ground and tree nuts storage at two moisture levels. International Journal of Agriculture \& Biology.14: 521-527. 
Magan, N., Hope, R., Cairns, V and Aldred, D. 2003. Post-harvest fungal ecology: Impact of fungal growth and mycotoxin accumulation in stored grain. European Journal of Plant Pathology. 109: 723730.

Mutegi C.K., Wagacha J.M., Christie M.E., Kimani J., Karanja L. 2013. Effect of storage conditions on quality and aflatoxin contamination of Peanuts (Arachis hypogaea L.). International Journal of Agri Science. Vol. 3(10): 746-758.

Ramamoorthy, K., and Karivaratharaju, T.V. 1989. Influence of pod and kernel treatments on the field performance of groundnut (Arachis hypogaea. L.) cv. Pol.2 after twelve months of storage.
Seeds Farms.15: 15-19.

Roberts, R.G., Morrison WH., Robertson JA and Hanlin RT. 1987. Extracellular lipase production by fungi from sunflower seed. Mycologia. 79:265-273.

Shin, T.S., and Godber, S. 1996. Changes of endogenous antioxidants and fatty acid composition in irradiated rice bran during storage. Journal of Agricultural and Food Chemistry. 44: 567-573.

Statistical year book of Telangana, 2015.

Weinberg, Z.G., Yan, Y., Chen, Y., Finkelman, S., Ashbell, G and Navarro, S. 2008. The effect of moisture level on high moisture maize (Zea mays L.) under hermetic storage conditions -in vitro studies. Journal of Stored Products Research. 44: 136-144.

\section{How to cite this article:}

Swathi, Y., P. Rajanikanth and Satyanarayana, J. 2017. Storage Method Influences the Fatty Acid Composition in Groundnut during Post-Harvest. Int.J.Curr.Microbiol.App.Sci. 6(10): 646654. doi: https://doi.org/10.20546/ijcmas.2017.610.079 